\title{
MODEL CERITA FIKSI KONTEMPORER ANAK-ANAK UNTUK PENGEMBANGAN KEMAHIRWACANAAN SISWA KELAS 5 SEKOLAH DASAR
}

\author{
Muakibatul Hasanah \\ Fakultas Sastra Universitas Negeri Malang \\ email: akibba.fs@um.ac.id
}

\begin{abstract}
Abstrak
Penelitian ini bertujuan untuk menemukan model fiksi kontemporer anak untuk meningkatkan literasi siswa kelas lima sekolah dasar (SD). Penelitian ini menggunakan rancangan hermeneutika kualitatif. Sumber data adalah buku fiksi kontemporer untuk anak dan tanggapan siswa kelas lima SD. Data dikumpulkan melalui analisis isi dan refleksi analitik. Temuan penelitian menunjukkan bahwa: (a) tanggapan siswa positif; (b) buku-buku fiksi memiliki struktur plot/narasi tunggal, sederhana, dan linier, memiliki gaya dramatis dan naratif, dan memiliki tema dan nilai yang beraneka ragam; dan (c) fiksi kontemporer untuk anak memberikan sumbangan pada peningkatan literasi.
\end{abstract}

Kata kunci: peningkatan literasi, fiksi kontemporer untuk anak, tanggapan pembaca dan siswa

\section{A CONTEMPORARY FICTION STORY MODEL FOR CHILDREN TO DEVELOP THE DISCOURSE COMPETENCE OF YEAR FIVE ELEMENTARY SCHOOL STUDENTS}

\begin{abstract}
This study aims to find a model for children's contemporary fiction to improve the literacy of the fifth grade students of elementary schools. It employed a qualitative hermeneutics design. The data resources were children's contemporary fiction books and responses of the fifth grade students of elementary schools. The data were collected through content analysis and analytic reflection. The findings show that: (a) the students' responses are positive; (b) the books have a single, simple, and linear plot/narrative structure, have a dramatic and narrative style, and have various themes and values; and (c) children's contemporary fiction contributes to the literacy improvement.
\end{abstract}

Keywords: literacy improvement, children's contemporary fiction, readers' and students' responses

\section{PENDAHULUAN}

Dalam era informasi yang ditandai dengan tindak komunikasi tulis atau simbol-simbol grafis dan elektronis, warga masyarakat dituntut memiliki kemahirwacanaan (literacy/literate thinking) (Joni, 1990). Kemahirwacanaan perlu dikembangkan sejak dini, tepatnya sejak anak memasuki lingkungan pendidikan dasar. Hal ini menjadi menarik jika dikaitkan dengan kompetensi dasar yang diharapkan dimiliki tamatan SD, yang di antaranya adalah kompetensi berpikir logis, kritis, kreatif dalam berkomunikasi lisan dan tulis melalui berbagai media, termasuk teknologi informasi (Depdiknas, 2001, 2003, 2006). Kompetensi tersebut diharapkan dapat dikembangkan melalui pembelajaran bahasa dan sastra Indonesia.

Terkait dengan tuntutan pembentukan kompetensi yang dimaksud, peranan pengajaran bahasa Indonesia di SD menjadi sangat penting. Dalam pengajaran 
bahasa Indonesia di SD yang bertumpu pada kemampuan dasar "baca-tulis", siswa SD tidak hanya dituntut untuk menguasai tahap pengenalan wacana (di kelas-kelas awal) tetapi juga pada tercapainya kemahirwacanaan (di kelaskelas tinggi). Kemahirwacanaan dalam konteks ini sejalan dengan konsep kemahirwacanaan yang dikemukakan Wells (dalam Joni, 1990). Wells mencoba menghubungkan kemampuan berpikir dengan kemampuan berwacana (literatel literacy thinking). Konsep literacy didefinisikan dalam pengertian yang lebih luas daripada sekedar kemampuan menggunakan simbol-simbol pesan dalam bentuk tulisan. Wells mengartikan literacy sebagai kemampuan bergaul dengan wacana sebagai representasi pengalaman, pikiran, perasaan, dan gagasan secara tepat sesuai dengan tujuannya.

Tujuan penciptaan wacana menurut Wells terbagi menjadi tiga kelompok, yaitu (1) sebagai alat untuk mempengaruhi tindakan secara langsung, (2) menyediakan informasi yang dapat dirujuk sewaktu-waktu, dan (3) menyajikan hasil kajian penulis tentang aspek pengalaman tertentu, baik riiil maupun imajiner, yang berkenaan dengan pemikiran, perasaan, pilihan nilai, serta pergulatan batin lain. Pergaulan ragam ketiga dengan wacana yang ditandai pemikiran kritis imajinatif itulah yang disalin oleh Joni sebagai kemahirwacanaan (literate thinking). Baik membaca maupun menulis yang dilakukan dalam modus kemahirwacanaan ditandai oleh kegiatan berpikir yang intens-penciptaan makna yang sangat mempribadi dengan mengerahkan segenap khazanah pengalaman, menggauli gagasan melalui analisis dan sintesis, proses membandingkan dan mempertentangkan, serta mengakomodasi dan mengasimilasikan berbagai pengalaman tersebut.

Kemahirwacanaan akan berkembang dengan sangat baik jika memanfaatkan cerita yang disukai anak-anak. Anak-anak usia sekolah dasar (SD) lazimnya senang akan cerita (Huck, 1987; Wollman-Bonilla dan Werchadlo, 1995). Huck menegaskan bahwa siswa SD kelas rendah menyukai cerita "hitam-putih" dan anak-anak kelas tinggi menyukai cerita realistik. WollmanBonilla dan Werchadlo (1995) menemukan fakta bahwa anak-anak kelas satu pun mau dan mampu merespon serita fiksi yang dibacakan untuk mereka melalui pemanfaatan jurnal respon sastra dengan respon yang berkembang dari yang berpusat pada teks menuju respon yang berpusat pada pembaca. Bahkan, Sebesta (1995) menemukan respon anak yang lebih rinci dalam perkembangannya, yakni dari tahap evokatif, alternatif, ke tahap berpikir reflektif dan evaluatif sejalan dengan perkembangan usianya.

Hal tersebut dapat dipahami mengingat anak-anak usia 7-12 tahun ada dalam taraf perkembangan kognitif: operasi konkret dan operasi formal awal (Piaget, 1951). Pada taraf ini anak baru dapat berpikir sistematis terhadap hal atau objek konkret. Terkait dengan taraf perkembangan tersebut, buku cerita secara potensial berisikan pesan-pesan moral dan persoalan yang dikonkretkan melalui peran yang dimainkan oleh tokoh-tokoh dalam cerita.

Dengan karakteristik yang demikian, buku cerita dapat menjadi media bagi pengembangan sikap sosial, emosi dan potensi intelektual anak-anak sebagaimana dilaporkan Knoeller (1994), Friend dan Davis (1993), serta Ackerman (1991). Menurut Knoeller (1994), dengan memanfaatkan cerita dalam pembelajaran, selain kemampuan mengapresiasi cerita dan baca-tulis, berkembang pula aspek sosial pada diri siswa. Friend dan Davis (1993) melaporkan bahwa cerita fiksi dapat digunakan untuk memancing respon emotif pada anak. Ackerman (1991) mendapati kenyataan bahwa cerita fiksi dapat digunakan untuk melihat perkembangan intelektual anak, khususnya yang 
berkaitan dengan kemampuan dalam membuat inferensi kausal.

Buku cerita dapat digunakan sebagai landasan tumpu dalam program pembelajaran kemampuan berbahasa (literaturebased program) di SD. Program tersebut terbukti dapat mengembangkan kemampuan berbahasa siswa (Huck dkk., 1987). Penelitian yang dilaporkan oleh McGee dan Tompkins (1995), Dole dkk. (1995), Menchaca dan Whitehurst (1992), Silli (1999), serta Simpson (1992) membuktikan bahwa cerita fiksi dapat dimanfaatkan untuk mengembangkan kemampuan membaca, mempercepat perluasan kosakata, mempercepat kemampuan berbicara secara signifikan, dan mengembangkan kemampuan menggunakan penanda kohesi dalam menulis.

Pelaksanaan program dimaksud di $\mathrm{SD}$, terutama di kelas tinggi, bergantung pada tersedianya buku cerita fiksi kontemporer (CFK) yang bermutu dan memiliki keunikan yang mampu memikat anakanak sehingga dapat memenuhi rasa ingin tahu dan kebutuhan iimajinatif anak. CFK merupakan padanan istilah fiksi realistik kontemporer (contemporary realistic fiction), yaitu salah satu genre fiksi anak-anak yang menyajikan "masalah riil" (contemporary) yang sangat mungkin terjadi dalam kehidupan manusia di alam fisik kita ini. CFK merupakan kebalikan dari cerita fantasi yang mengangkat peristiwa yang tidak mungkin terjadi tetapi dibuat menjadi mungkin, berbeda pula dengan cerita fiksi sejarah yang menggambarkan kehidupan yang mungkin telah terjadi di masa lampau. CFK berfokus pada problematika kehidupan masa kini. Dengan demikian, CFK dapat berfungsi membantu anak memahami diri sendiri. CFK yang menggambarkan realitas kehidupan membantu anak untuk lebih memahami problem dan hubungan antarmanusia sehingga anak lebih memahami diri dan potensi diri.
Buku CFK berisikan informasi yang dekat dengan realitas kehidupan anak sehari-hari. Galda (1993) mengatakan bahwa buku cerita yang bermutu dan berisikan beragam struktur berguna untuk mengisahkan cerita, mengekspresikan emosi, serta menyajikan informasi. Pajanan beragam buku cerita yang bermutu akan memahamkan anak terhadap teksteks baru melalui skema organisasional.

Beragam buku cerita fiksi kontemporer terutama yang tersedia di luar sekolah dapat memenuhi rasa ingin tahu dan kebutuhan imajinatif anak. Sebagian besar buku cerita fiksi kontemporer yang sangat disukai anak adalah buku cerita yang diperdagangkan, sementara buku-buku cerita yang tersedia di sekolah kurang memadai dan kurang disukai anak-anak, mengingat cerita tersebut rendah kualitas literer dan format tampilannya (Periksa temuan Dermawan, 2005). Buku cerita tersebut lebih disukai karena diasumsikan memiliki karakteristik struktur naratif, teknik penceritaan, dan isi yang mampu memikat anak-anak.

Kurangnya buku-buku cerita fiksi kontemporer yang memadai dan memikat dimungkinkan karena penulis cerita anakanak kesulitan menulis cerita yang sesuai dengan minat anak. Untuk itu, diperlukan model CFK yang memenuhi syarat, baik syarat kultural-edukatif, maupun syarat informatif-imajinatif. Buku cerita yang demikian dapat dikatakan memiliki kualitas struktur naratif, teknik penceritaan, dan isi yang sesuai dengan tuntutan tersebut. Dengan demikian, diperlukan model buku CFK anak-anak yang diperoleh melalui penelitian yang bertumpu pada teks cerita anak-anak dan respon anakanak terhadap CFK.

Secara umum, penelitian ini bertujuan menemukan model CFK anak-anak sebagai dasar bagi pengembangan kemahirwacanaan siswa SD. Secara rinci tujuan penelitian ini mendeskripsikan: (1) respon siswa SD terhadap CFK anak-anak 
dilihat dari (a) minat siswa dan (b) tingkat respon siswa; (2) karakteristik CFK anakanak yang mendapat respon positif siswa dilihat dari (a) struktur naratif, (b) teknik penceritaan, dan (c) isi CFK anak-anak; serta (3) sumbangan CFK anak-anak terhadap pengembangan kemahirwacanaan siswa SD.

\section{METODE}

Berdasarkan tujuan penelitian, rancangan yang digunakan dalam penelitian ini adalah rancangan penelitian kualitatif hermeneutis. Dikatakan demikian, karena secara kualitatif interpretatif dengan penelitian ini dideskripsikan model CFK anak-anak yang dapat mengembangkan kemahirwacanaan siswa SD.

Subjek penelitian ini adalah sejumlah siswa dari SDN Tulusrejo I Kecamatan Lowokwaru Kodya Malang yang duduk di kelas 5 pada tahun pelajaran 2003/2004. Selama satu semester subjek diberi bukubuku dalam jumlah yang memadai sehingga memungkinkan subjek memilih sendiri buku yang disukainya.

Data penelitian ini dikumpulkan dengan instrumen pengumpul data penelitian ini adalah instrumen manusia, yaitu peneliti sendiri yang dilengkapi dengan instrumen penunjang yang berupa (1) instrumen jurnal membaca dan angket tentang respon siswa; (2) instrumen pengumpul data karakteristik struktur naratif, teknik penceritaan, dan isi cerita; (3) instrumen identifikasi kebutuhan kemahirwacanaan, serta instrumen hasil pengembangan kemahirwacanaan.

Pengumpulan data dilakukan dengan teknik dokumentasi atau kajian kepustakaan/teks/wacana dengan disertai pemahaman dan pemerian mendalam. Teknik tersebut diwujudkan dengan membaca secara kritis-evaluatif CFK yang dijadikan sumber data, respon tulis siswa, serta hasil belajar baca tulis siswa sampai mencapai titik jenuh sehingga diperoleh pemahaman dan pemerian arti yang mendalam.
Data yang terkumpul dalam instrumen pengumpul data dianalisis dengan teknik sebagai berikut. Analisis data penelitian dikerjakan dengan menggunakan teknik (a) pemahaman arti secara hermeneutis menurut asas Dilthey, Gadamer, dan Ricour, (b) analisis isi (content analysis) khususnya analisis domain menurut Spradly, dan (c) analisis interaktif (Poespoprodjo, 1986; Ricour, 1991; Spradly, 1997; Sumaryono, 1993; Miles dan Huberman, 1992).

\section{HASIL DAN PEMBAHASAN}

Sesuai dengan tujuan penelitian ini, pada bagian ini dideskripsikan tiga hal, yaitu: (1) respon siswa SD terhadap CFK anak-anak dilihat dari (a) minat siswa dan (b) tingkat respon siswa; (2) karakteristik CFK anak-anak yang mendapat respon positif siswa dilihat dari (a) struktur naratif, (b) teknik penceritaan, dan (c) isi CFK anak-anak; serta (3) sumbangan CFK anak-anak terhadap pengembangan kemahirwacanaan siswa SD.

\section{Respon Siswa terhadap CFK}

Paparan hasil analisis data respon siswa terhadap CFK disajikan dengan dipilah atas: (a) minat siswa, dan (b) tingkat respon siswa. Paparan hasil penelitian disajikan dalam sub-sub bab sebagai berikut.

\section{Minat Siswa}

Berdasarkan hasil analisis ditemukan bahwa minat siswa terhadap CFK sangat tinggi. Indikator pertama dari tingginya minat adalah perilaku ketertarikan siswa yang dapat dilihat dari reaksi mereka ketika diberi kesempatan melihat-lihat dan memilih buku CFK dan pada saat selesai membaca. Pada saat memilih buku, sebagian besar siswa menyatakan rasa ketertarikannya pada judul (90\%), pada sampul $(50 \%)$, dan pada isi ringkasan (36\%). Pada saat selesai membaca, sebagian besar siswa menyatakan bahwa isi buku sangat

Model Cerita Fiksi Kontemporer Anak-Anak Untuk Pengembangan Kemahirwacanaan Siswa ... 
menarik $(82 \%)$, sementara sisanya $(18 \%)$ menyatakan cukup menarik.

Minat yang sangat tinggi dimungkinkan karena format, tampilan buku, serta penyajian buku-buku CFK cukup memikat. Format buku-buku CFK yang diminati siswa sebagian besar dapat dinilai memadai jika dihubungkan dengan perkembangan siswa. Siswa kelas 5 SD yang menjadi subjek penelitian dipandang dapat menerima ukuran buku 13,5×20 cm dengan ukuran dan kerapatan huruf 14-16. Banyaknya ilustrasi gambar dalam teks juga turut mendukung kuatnya minat siswa.

Tampilan gambar dan warna pada sampul juga menjadi faktor pendukung tumbuhnya minat siswa. Gambar dengan warna-warna terang pada buku CFK yang diminati siswa umumnya dapat "bercerita" tentang isi buku. Dengan melihat gambar pada sampul dan ilustrasi, siswa memperoleh gambaran sekilas tentang isi cerita. Warna-warna yang mencolok juga memikat karena pada dasarnya anak suka akan warna. Selain itu, buku-buku CFK sengaja disajikan dalam rak pamer bersekat kaca sehingga sampul buku-buku CFK dapat langsung dilihat atau menghadap ke arah siswa yang melihatnya.

Indikator lainnya dari minat siswa terhadap buku-buku CFK adalah frekuensi baca siswa. Rata-rata (r) baca siswa 2,7 buku CFK per minggu dengan rentang 2-4 buku CFK. Rata-rata baca selama perlakuan setiap siswa 30 buku CFK dengan rentang 19-42 buku CFK. Dengan melihat frekuensi baca setiap siswa per minggu dan selama perlakuan dapat dikatakan bahwa siswa rajin membaca buku CFK. Dengan kata lain, minat baca CFK pada siswa tinggi. Bandingkan dengan frekuensi baca buku penunjang pelajaran BI 1 buku per semester atau bahkan per tahun pelajaran.

Temuan tentang minat baca CFK membuktikan pendapat Huck dkk. (1987) yang menunjukkan bahwa siswa kelas tinggi menyukai CFK. Huck menegaskan bahwa siswa SD kelas rendah menyukai cerita "hitam-putih" dan anak-anak kelas tinggi menyukai cerita kontemporer. Purwo (1991) berpendapat bahwa anak-anak lebih tertarik pada buku cerita daripada buku pelajaran.

Hal ini dapat dipahami mengingat anak-anak usia 7-12 tahun ada dalam taraf perkembangan kognitif yang dinamakan tingkat operasi konkret dan operasi formal awal (Piaget, 1951). Pada taraf ini anak baru dapat berpikir sistematis terhadap hal atau objek konkret dan mulai berpikir abstrak. Terkait dengan taraf perkembangan tersebut buku cerita secara potensial berisikan pesan-pesan yang dikonkretkan melalui peran yang dimainkan oleh tokoh-tokoh dalam cerita.

Cukup tingginya frekuensi baca siswa selama masa perlakuan dimungkinkan karena tersedianya buku CFK secara cukup sehingga dapat memuaskan kebutuhan mereka akan bacaan alternatif. Hal tersebut berkaitan dengan prasyarat penerapan pendekatan respon pembaca di kelas, yakni bahwa karya sastra tersedia secara memadai dan dibaca baik oleh guru maupun siswa (Sayuti, 1998).

Sejak kelas I SD, para siswa hanya membaca buku-buku pelajaran. Buku-buku bacaan yang tersedia di perpustakaan sekolah umumnya tidak termanfaatkan dalam pembelajaran bahasa secara optimal. Selain itu, di perpustakaan sekolah belum banyak koleksi buku cerita yang dapat memenuhi kebutuhan dan perkembangan siswa.

Tingginya minat baca CFK mengindikasikan bahwa CFK dapat membangkitkan kesenangan siswa sebagaimana dikatakan Iser (1974) bahwa teks sastra haruslah berisikan sesuatu yang dapat melibatkan imajinasi pembaca sehingga memungkinkan pembaca memperoleh kesenangan. 


\section{Jenis dan Tingkat Respon Siswa}

Berdasarkan hasil analisis atas data respon ditemukan bahwa respon siswa terhadap buku-buku CFK beragam dan secara bertahap berkembang mulai level eferen sampai level berpikir reflektif. Pada tahap awal, respon siswa berada pada level eferen. Pada perkembangan selanjutnya, respon semua siswa berkembang ke level evokatif, yakni berupa penceritaan kembali sebagian isi cerita dan penggambaran tokoh serta peristiwa yang dianggap menarik; dan sebagian ke level empatetik, yakni bersimpati/bereaksi terhadap tokoh cerita dan membayangkan apa yang dirasakan tokoh cerita. Sebagian besar respon siswa berkembang ke level alternatif (60\%). Respon sebagian kecil siswa (15\%) bahkan sudah mencapai level berprikir reflektif. Siswa memperoleh "makna" dari isi cerita.

Temuan tentang berkembangnya respon siswa menguatkan temuan Wollman-Bonilla dan Werchadlo (1995), bahwa siswa kelas 1 pun sudah mampu merespon cerita. Adapun temuan jenis respon dapat dihubungkan dengan hasil penelitian Sebesta (1995) yang menunjukkan bahwa kategori respon siswa kelas 4-6 SD 27\% pada tahap evokasi, $41 \%$ pada tahap alternatif, dan $2 \%$ pada tahap berpikir reflektif. Respon yang beragam menunjukkan kebenaran teori Iser (1974) bahwa karya sastra dapat menimbulkan kesan tertentu pada pembacanya.

\section{Karakteristik CFK yang Direspon Siswa SD}

Paparan hasil analisis data karakteristik CFK yang direspon siswa SD disajikan dengan dipilah atas: (a) karakteristik struktur naratif, (b) karakteristik teknik penceritaan, dan (c) karakteristik isi CFK.

\section{Karakteristik Struktur Naratif CFK}

Struktur naratif CFK yang direspon siswa mengikuti pola alur tunggal, sederhana, dan linier. Rangkaian peristiwa da- lam cerita dimulai dari paparan, konflik, klimaks, dan selesaian.

Paparan. Paparan berisi deskripsi keadaan dan karakteristik tokoh. Deskripsi keadaan meliputi deskripsi suasana dan cuaca sebagaimana terlihat pada bagian paparan pada cerita Hadiah, Iiih Takut, dan Si Ehem. Paparan tokoh berupa deskripsi keinginan tokoh dan karakteristik tokoh sebagaimana dalam cerita Kamar Baru dan Rahasia Lembah Terlarang. Bagian paparan dalam CFK disajikan secara ringkas karena hanya berfungsi untuk mengantarkan pembaca memasuki konflik dalam cerita.

Konflik. Konflik cerita diawali dengan rangkaian peristiwa keadaan yang menunjukkan adanya pertentangan. Pertentangan yang terjadi berupa (1) pertentangan antara keadaan di sekeliling tokoh dengan suasana batin tokoh, (2) pertentangan antara keadaan dengan keingin/ harapan tokoh, dan (3) pertentangan batin tokoh sebagaimana konflik dalam cerita Lupus Membolos dan Saudara Tiri. Konflik dalam CFK pada umumnya bersifat tunggal yang dibangun dan dirangkai dengan peristiwa-peristiwa yang memperuncing konflik.

Konflik merupakan bagian penting (kunci) dalam struktur naratif CFK. Tanpa konflik CFK menjadi tidak menarik. Oleh karena itu, di dalam CFK konflik dimunculkan sesudah paparan. Bagian ini pula yang mengikat minat siswa untuk mengikuti lanjutan cerita.

Klimaks. Klimaks dalam CFK merupakan lanjutan konflik. Bagian klimaks berisi peristiwa tragis, peristiwa pada saat menjelang terbukanya misteri, dan keadaan yang sangat mengecewakan.

Selesaian. Selesaian dalam CFK merupakan bagian yang disusun sebagai antiklimaks. Bagian ini cukup singkat yang disusun untuk segera mengakhiri cerita. Sebagai bagian penutup, selesaian dalam CFK dibuat melegakan pembaca (anakanak). Misalnya, tokoh utama selamat,

Model Cerita Fiksi Kontemporer Anak-Anak Untuk Pengembangan Kemahirwacanaan Siswa ... 
konflik teratasi, kondisi membaik, atau kesadaran tokoh mulai tampak sebagaimana terlihat pada cerita: Hadiah, Rahasia Lembah Larangan, Saudara Tiri, dan Duit Lebaran.

\section{Karakteristik Teknik Penceritaan}

Teknik penceritaan yang dominan dalam CFK adalah teknik diegetik dan dramatik. Teknik diegetik (telling menurut Kate, 2000) digunakan oleh pengarang untuk memaparkan latar tempat dan karakteristik tokoh. Teknik diegetik dalam CFK berupa rincian tempat, keadaan, dan tokoh. Teknik diegetik selain digunakan pada bagian paparan (awal cerita) juga digunakan pada bagian lain dalam cerita.

Teknik dramatik yang mewujud dalam bentuk dialog selalu muncul dalam setiap bagian dalam struktur naratif, bahkan pada bagian paparan yang umumnya menggunakan teknik diegetik. Sebagian kecil CFK menggunakan dialog sebagai pembuka cerita, sebagaimana contoh dalam cerita Lupus Membolos. Penggunaan Dialog dalam bagian cerita juga dijumpai dalam cerita Saudara Tiri.

Penggunaan teknik diegetik dan dramatik dalam bentuk dialog dalam CFK cukup dominan, sedangkan dalam bentuk monolog sangat sedikit ditemukan dalam CFK. Dominannya teknik diegetik dimungkinkan karena pada umunya CFK ditulis dengan sudut pandang orang ketiga. Penutur selalu menempatkan dirinya sebagai pengamat dan bukan tokoh. Penutur cerita hampir selalu menyebut tokoh-tokoh cerita dengan namanya. Kata ganti "dia" atau "ia" hanya digunakan sesekali jika harus mengganti nama, penutur menggunakan sebutan lain misalnya "anak itu".

\section{Karakteristik isi CFK}

Paparan hasil analisis data isi CFK terpilah atas tema, amanat, dan nilai CFK. Tema-tema dalam CFK berhubungan dengan persoalan sehari-hari yang dapat dialami atau dijumpai di seputar kehidupan anak. Dalam skala terkecil bertalian dengan (1) lingkungan keluarga yang meliputi hubungan anak-orang tua dan anak dengan anak; (2) lingkungan di luar rumah meliputi kehidupan anak di sekolah dan di luar sekolah.

Tema yang terkait dengan lingkungan keluarga di antaranya terumuskan sebagai berikut: (a) pertentangan batin seorang anak melawan egoisme, rasa kasih sayang kepada orang tua akhirnya meluluhkan egoisme anak (Hadiah); (b) keluguan anak-anak tetap terlihat sekalipun dia pintar, mereka tetap nakal, lucu, dan menggemaskan (Emil dari Lönneberga); (c) anak suka kamar sendiri sekalipun masih takut tidur sendiri (Dapat Kamar Baru); (d) seorang anak kecil yang dihantui rasa takut karena ditinggal sendiri di malam hari (Iiih, Takuuuut!); (e) karena alasan penghematan yang dilakukan orang tua seorang anak harus menderita lebih lama (Terserang Si Ehem); (f) kegelisahan seorang anak ketika harus berbagi kasih sayang ayahnya dengan saudara tirinya (Saudara Tiri); (g) kekonyolan yang dilakukan seorang anak lantaran menginginkan duit lebaran sehingga kehilangan kesempatan berlebaran dengan saudaranya (Duit Lebaran).

Tema yang berkaitan dengan lingkungan di luar rumah di antaranya terumuskan sebagai berikut: (a) rasa ingin tahu mendorong anak-anak berani menantang bahaya (Rahasia Lembah Terlarang).; (b) perasaan bersalah menghantui anak baik yang terpaksa melakukan kesalahan dengan bolos sekolah (Lupus Membolos); (c) misteri atau rahasia suatu peristiwa dapat terpecahkan dengan berpikir keras (Rahasia Ular Piton); (d) kejujuran dan kecerdikan seorang anak terlihat dari cara dia bercerita dan menanggapi persoalan (Diuji dengan Mimpi); (e) dengan persiapan dan perhitungan yang matang seseorang dapat mengatasi bahaya (Fathia di Sarang Peracun). 
Amanat dalam CFK berupa pernyataan pengarang sebagai upaya untuk mengatakan sesuatu. Amanat dalam CFK disajikan secara tersurat dan tersirat. Penyajian secara tersurat ditemukan dalam (1) ucapan salah satu tokoh, atau (2) komentar pengarang. Berikut ini contoh bentukbentuk amanat dalam CFK: (a) jangan melakukan kesalahan jika tidak ingin dihantui rasa bersalah, dan (b) berbagi kasih sayang mama dan papa dengan saudara tiri lebih baik daripada hanya menerima kasih sayang dari seorang mama atau papa saja.

Amanat yang tersirat dapat ditafsirkan melalui tema cerita atau dari keseluruhan isi cerita sebagaimana contoh berikut.

(a) Terimalah perilaku/kenakalan anakanak secara wajar. Orang tua tidak perlu menyikapinya dengan berlebihan (Emil dari Lönneberga). Amanat tersebut merupakan penafsiran dari tema "keluguan anak-anak tetap terlihat sekalipun dia pintar. Sebagai anak-anak, mereka tetap nakal, lucu, dan menggemaskan".

(b) Rasa percaya diri dalam mengatasi bahaya dapat ditumbuhkan dengan menambah pengetahuan dan melatih kecerdikan (Fathia di Sarang Peracun). Amanat tersebut ditafsirkan melalui keseluruhan teks cerita dan melalui tema "cerita dengan persiapan dan perhitungan yang matang seseorang dapat mengatasi bahaya".

Penyajian amanat secara tersirat dilakukan oleh pengarang sebagai upaya untuk memberikan kesan bahwa pengarang tidak ingin mengajari pembaca. Namun, bagaimanapun pengarang selalu ingin mengatakan sesuatu dengan cara yang sangat halus. Dengan demikian, sebagaimana tokoh, siswa (pembaca) diajak untuk selalu berpikir, merenung, dan berusaha mengatasi sendiri masalah yang dihadapinya. Anak diajari mandiri melalui proses berpikir.
Nilai CFK. Berdasarkan paparan temuan tema dan amanat dalam CFK dapat ditafsirkan nilai-nilai dalam CFK. Nilai-nilai yang dimaksud adalah nilai kasih sayang, keberanian, kepolosan, kebahagiaan, kejujuran, dan kemandirian. Nilai kasih sayang diperoleh dari penasiran tema-tema: pertentangan batin seseorang anak melawan egoisme dan rasa kasih sayang kepada orang tua akhirnya meluluhkan egoisme anak, dan kegelisahan seorang anak ketika harus berbagi kasih sayang ayahnya dengan saudara tirinya.

Nilai keberanian diperoleh dari penafsiran tema-tema berikut.

(a) Misteri atau rahasia suatu peristiwa dapat terpecahkan dengan berpikir keras.

(b) Rasa ingin tahu mendorong anak-anak berani menantang bahaya.

(c) Seorang anak kecil dihantui rasa takut karena ditinggal sendiri di malam hari.

(d) Dengan persiapan dan perhitungan yang matang seseorang dapat mengatasi bahaya.

Nilai kepolosan diperoleh dari penafsiran tema-tema berikut: (a) keluguan anak-anak tetap terlihat sekalipun mereka pintar, sebagai anak-anak mereka tetap nakal, lucu, dan menggemaskan; (b) kekonyolan yang dilakukan seorang anak lantaran menginginkan duit lebaran sehingga kehilangan kesempatan berlebaran dengan saudaranya. Nilai kebahagiaan diperoleh dari penafsiran tema "karena alasan penghematan yang dilakukan orang tua seorang anak harus menderita lebih lama".

Nilai kejujuran diperoleh dari penafsiran tema-tema berikut: (a) erasaan bersalah menghantui anak baik yang terpaksa melakukan kesalahan dengan bolos sekolah, serta (b) kejujuran dan kecerdikan seorang anak terlihat dari cara dia bercerita dan menanggapi persoalan. Nilai kemandirian diperoleh dari 
penafsiran tema "anak suka kamar sendiri sekalipun masih takut sendirian".

Berdasarkan paparan terlihat isi CFK sangat beragam, terutama dilihat pada temuan nilai CFK. Beragamnya isi CFK dimungkinkan oleh upaya penulis untuk mengangkat beragam kehidupan anak yang memang sangat kaya sejalan dengan perkembangan pengalaman dan meluasnya lingkungan kehidupan anak. Tematema CFK yang diangkat dari kehidupan anak akan membuat anak dengan cepat mempersepsi, merenungkan, dan mengaktualisasikan isi CFK yang dibacanya.

\section{Sumbangan CFK untuk Kemahirwaca- naan Siswa SD}

Temuan karakteristik CFK direfleksikan dan dikaitkan dengan hasil kajian tuntutan kemahirwacanaan untuk siswa SD. Hasil refeksi disajikan dengan paparan yang terpilah atas (1) tuntutan kemahirwacanaan siswa SD dan (2) sumbangan CFK untuk pengembangan kemahirwacanaan.

\section{Tuntutan Kemahirwacanaan Siswa SD}

Paparan temuan tuntutan kemahirwacanaan didasari kajian terhadap teori perkembangan bahasa anak, pendekatan komunikatif, dan kurikulum pendidikan bahasa di SD. Uraian selengkapnya terpapar sebagai berikut.

Berdasarkan pendekatan komunikatif, tuntutan kemahirwacanaan siswa SD adalah terbinanya kemampuan siswa dalam menggunakan bahasa Indonesia untuk fungsi-fungsi: (1) interaksional, penggunaan bahasa untuk berinteraksi dengan orang lain, (2) personal, penggunaan bahasa untuk mengekspresikan perasaan/ pesan; (3) imajinatif, penggunaan bahasa utuk mengembangkan dunia imajinatif, dan (4) fungsi representasional, penggunaan bahasa untuk mengomunikasikan informasi.
Berdasarkan kajian teori perkembangan bahasa anak, tuntutan kemahirwacanaan siswa SD adalah berkembangnya potensi berbahasa anak yang sudah dimiliki anak sejak berusia 2 tahun. Anak usia SD memiliki potensi berbahasa secara kreatif. Potensi tersebut dapat dilacak sejak anak dapat menghasilkan bunyi-bunyi yang merupakan cikal bakal bunyi-bunyi bahasa. Peran pembelajaran di sekolah adalah mengoptimalkan berkembangnya potensi bahasa yang dimiliki anak sehingga mereka mampu berbahasa secara kreatif-komunikatif.

Guru dapat menerapkan pendekatan interaksionis. Oleh karena pada tahap awal siswa terlibat interaksi dalam kelompoknya dengan membawa pengetahuan awal, maka melalui interaksi ini ujaran dalam menjadi dasar kemampuan lisan. Kemampuan lisan inilah yang dapat ditransformasikan ke dalam komunikasi tulis sehingga sumber asli tulisan adalah ujaran bagian dalam yang diperoleh dari ujaran egosentris. Dalam menulis, seorang anak dapat berproses dari ujaran dalam ke dalam ujaran tulis.

Dalam aktivitas tersebut anak kemungkinan besar hanya akan menghasilkan tulisan spontan. Karenanya, guru perlu memberi komentar, catatan dan dorongan yang berguna dalam memajukan kemampuan menulis siswa. Cara lain yang dapat digunakan adalah dengan mengadakan pertemuan atau konferensi individual untuk mendiskusikan perkembangan tulisan siswa.

Berdasarkan kajian kurikulum pendidikan dasar, khususnya Kurikulum Berbasis Kompetensi, tuntutan kemahirwacanaan siswa SD mengacu pada standar kompetensi membaca dan menulis serta kompetensi bersastra.

Struktur naratif CFK anak-anak berciri tunggal, sederhana, dan linier. CFK yang berstruktur naratif demikian dapat difungsikan untuk memfasilitasi siswa dalam memenuhi tuntutan kemahiran mem- 
baca intensif, yakni "menyusun cerita dari kalimat acak", "memahami teks dan menyusun ringkasannya", "serta membaca cepat teks dan memahami isinya".

Selain itu, CFK dengan struktur sederhana dan linier dapat difungsikan untuk mengembangkan kemahiran menulis "melanjutkan cerita narasi". Dengan melihat/membaca cerita yang sederhana dan linier, siswa dapat belajar melengkapi cerita dalam urutan yang sederhana dan linier pula, serta mengembangkan kemahiran "menulis secara ringkas dari cerita". Hal ini dapat ditempuh dengan prosedur: kepada siswa diperdengarkan atau siswa membaca CFK yang terpotong bagian akhirnya, kemudian siswa diminta mengidentifikasi rangkaian peristiwa dalam CFK, dan memprediksi peristiwa apa yang akan terjadi kemudian. Dengan prediksi tersebut siswa ditugasi menyelesaikan akhir ceritanya.

Sumbangan CFK dalam kemahirwacanaan dapat dihubungkan dengan kekhasan teknik penceritaannya. Teknik penceritaan dalam CFK anak-anak yang dominan adalah teknik naratif dan dramatik. CFK dengan teknik dramatik yang diwujudkan dalam dialog dapat difungsikan untuk mengembangkan kemahiran siswa dalam "membacakan teks percakapan dengan lafal dan intonasi yang tepat". Hal tersebut dapat dilakukan dengan meminta siswa untuk memilah teks dialog dan teks nondialog dalam CFK untuk dibawakan di kelas. Selain itu, CFK dengan teknik dramatik dapat difungsikan untuk mengembangkan kemahiran "melengkapi percakapan yang belum selesai". Bahkan, siswa dapat mengembangkan dialog setelah terinspirasi salah satu CFK Pesta Menginap sebagaimana yang telah dilakukan Dita, Novita dan Emilia.

CFK dengan teknik dramatik juga dapat difungsikan bagi pengembangan kemahiran "menulis surat untuk teman sebaya dengan bahasa yang komunikatif". Teknik dramatik menjadi model bagi siswa dalam berkomunikasi dengan temannya melalui surat, berkomunikasi dengan gaya monolog dan dialog, serta menulis catatan kejadian penting dalam buku harian karena teknik penuturan dalam surat pribadi dan teknik dalam buku harian memiliki kemiripan, yakni keduanya menggunakan bahasa percakapan, dalam surat pribadi seseorang berbicara dengan lawan tutur teman sebayanya sedangkan dalam buku harian seseorang berbicara dengan dirinya sendiri.

CFK dengan teknik diegetik yang sebagian berupa deskripsi dapat difungsikan untuk mengembangkan kemahiran siswa dalam "menulis deskripsi tentang benda-benda di sekitar atau tentang seseorang dengan bahasa yang runtut". Hal tersebut dapat dilakukan dengan memanfaatkan paragraf yang berisi deskripsi tempat, suasana, dan tokoh cerita. Strateginya, siswa diminta mengutip deskripsi tempat, suasana atau tokoh dalam CFK kemudian memilih tokoh (boleh dalam cerita dengan versi baru) yang sudah dikenalnya dan mengembangkannya dalam paragraf deskriptif. Siswa dapat pula diajak menyusun cerita berantai secara bersama-sama dengan rancangan cerita (tema, tokoh, latar, alur) yang disepakati di kelas. Kemudian setiap siswa di dalam kelompok mengembangkan bagian cerita dalam paragraf deskriptif. Dengan berpedoman pada langkah-langkah tersebut, tujuan agar siswa dapat menulis deskripsi dapat tercapai.

CFK dengan teknik naratif dan dramatik dapat difungsikan untuk mengembangkan kemahiran "menulis cerita berdasarkan pengalaman". Kualitas penceritaan yang dituntut adalah "... yang menarik sehingga pembaca dapat ikut membayangkan isi cerita". Tuntutan kualitas Teknik yang demikian dapat diwujudkan melalui paparan deskripsi karena semakin rinci suatu deskripsi semakin kuat efek pembayangannya pada pembaca, sedangkan Teknik dramatik

Model Cerita Fiksi Kontemporer Anak-Anak Untuk Pengembangan Kemahirwacanaan Siswa ... 
dapat menghidupkan cerita sebagaimana para tokoh berbicara dalam kehidupan sehari-hari. Hasilnya adalah sebuah cerita tentang pengalaman singkat yang menarik dan hidup.

Pada umumnya, kesulitan siswa dalam menuliskan pengalaman terjadi pada tahap memilih pengalaman yang menarik untuk ditulis. Untuk mengatasi kesulitan itu, maka CFK dapat memberikan pengalaman pilihan, yakni pengalaman imajinatif yang dapat dikembangkan oleh siswa.

Tema-tema CFK yang beragam memberi inspirasi bagi siswa untuk mengembangkan cerita rekaan. Tema-tema CFK yang dapat dikelompokkan ke dalam beragam jenis CFK memudahkan siswa untuk menggali tema. Tema cerita jenis misteri dapat diangkat sebagai tema cerita yang dikaitkan dengan refleksi oleh siswa. Siswa diajak mengembangkan empatinya dengan meminta membayangkan jika dia yang mengalami suatu peristiwa, apakah yang akan dilakukannya, bagaimana perasaannya, dan apakah dia perlu berbicara dengan orang lain?

Pertanyaan-pertanyaan itu akan memandu siswa mengembangkan ceritanya. Pada tataran ini siswa diharapkan memfungsikan kemahiran menyusun peristiwa dalam struktur yang kronologis (linier); menulis deskripsi tempat dan suasana; serta kemahiran menyusun dialog.

\section{SIMPULAN}

Perspektif teori respon pembaca atau resepsi pembaca Iser dan Rosenblatt dapat diimplementasikan dalam pembelajaran membaca cerita di sekolah (dimulai di SD) sebagai penyeimbang pembelajaran membaca yang berorientasi pada penulis. Implementasi teori tersebut memungkinkan keterlibatan siswa secara lebih apresiatif karena pembentukan makna terjadi dalam proses membaca melalui transaksi antara siswa dengan teks. Dalam memaknai teks, siswa akan membawa serta pengetahuan dan pengalamannya sehingga emosi dan kognisi siswa berkontribusi untuk membangkitkan pengetahuan dan pengalaman bersastranya.

\section{UCAPAN TERIMA KASIH}

Artikel ini disarikan dari penelitian mandiri pada tahun 2010. Ucapan terima kasih disampaikan kepada mahasiswa yang telah membantu pelaksanaan pengumpulan data, kepada mitra sejawat yang telah membantu kegiatan verifikasi dan triangulasi data serta kepada redaktur ahli yang telah memberikan masukan terhadap artikel ini. Semoga tulisan ini bermanfaat dalam upaya peningkatan kualitas pembelajaran bahasa dan sastra Indonesia, khususnya pembelajaran keterampilan berbahasa di sekolah dasar.

\section{DAFTAR PUSTAKA}

Golden, J.M. 1984. Children's Concept of Story in Reading and Writing. The Reading Teacher, 37:578-584.

Huck, C.S., S. Hepler, J. Hickman. 1987. Children's Literature in the Elementary School. New York: Holt-Rinehart.

Iser, W. 1974. The Reading Process: A Phenomenological Approach. Dalam Ralph Cohen (Ed.). New Directions in Literary History. London: RKP.

Iser, W. 1978. The Act of Reading. London: Routledge \& Kegan Paul.

Junus, U. 1985. Resepsi Sastra: Sebuah Pengantar. Jakarta: Garmedia.

Piaget, J. 1951. The Phsychology of Intelegence. Diterjemahkan oleh Piercy, Malcolm and Berlyne, D.E. London: Routledge \& Kegan Paul Ltd.

Purwo, B.K. 1991. Pengajaran Bahasa Indonesia di Sekolah Dasar. Makalah disajikan dalam Konferensi Nasional Keenam Masyarakat Linguistik Indonesia, Semarang, 7-13 Juli 1991.

Rosenblatt, L. 1985. The Reader, The Text, The Poem. Dalam Jana F. Mason (Ed.) Reading and Writing Connections. London: University of Illionis at Urbana. 
Sebesta, S.L. 1995. A Hierarchy to Asses Reader Response. Journal of Reading, 38(6):444-450.

Sayuti, S.A. 1998. Strategi Transaksional dalam Pengajaran Sastra: Sebuah Imperatif dari Teori Resepsi Wolfgang Iser. Bahasa dan Seni, 26(2): 158-178.

Sayuti, S.A. 2001. Menuju Pengajaran Sastra yang Ideal. Makalah disajikan dalam
Seminar Sehari Menyongsong Pemberlakuan Kurikulum Baru Bidang Studi Bahasa Indonesia, Malang, 22 Oktober 2001.

Wollman-Bonilla, J.E. \& Werchadlo, B. 1995. Literature Response Journals in a First Grade Classroom. Language Arts, 72(8):562-570. 